\title{
PENGUJIAN TOKSISITAS PRODUK HERBAL SECARA IN VIVO
}

\author{
Nurul Fatirah ${ }^{1, \dagger}$, Sabaniah Indjar Gama1, Rolan Rusli ${ }^{1,2, \downarrow}$ \\ ${ }^{1}$ Laboratorium Penelitian dan Pengembangan Kefarmasian "Farmaka Tropis", \\ Fakultas Farmasi, Universitas Mulawarman, Samarinda, Indonesia \\ †Email: nurul02.bengawan@ gmail.com \\ ${ }^{2}$ Kelompok Bidang Ilmu Kimia Farmasi, Fakultas Farmasi, \\ Universitas Mulawarman, Samarinda, Indonesia \\ Email: rolan@farmasi.unmul.ac.id
}

\begin{abstract}
The use of herbal products in the community is quite a lot. There are no further studies regarding the similarity of using " $X$ " herbal products. This study aims to determine the toxic effects of herbal $X$ products. . Toxicity testing was carried out by administering the preparation orally for 28 days in 4 groups of experimental animals, namely group 1 was given herbal product $X 1$, group 2 was given herbal product X2, group 3 was given herbal products X3 and group 4 was given aquadest. The toxicity parameters of herbal products used were changes in body weight, index of organs (liver and kidney), levels of SGOT and $S G P T$, as well as histopathological features of the liver. The results showed that $X$ herbal products did not cause toxic effects on experimental animals.
\end{abstract}

Keywords: herbal products, toxicity, histopathology

\begin{abstract}
ABSTRAK
Penggunaan produk herbal di masyarakat saat ini cukup banyak. Belum ada penelitian lebih lanjut mengenai keamaan penggunaan produk herbal " $X$ ". Penelitian ini bertujuan untuk mengetahui efek toksik dari produk herbal X. Pengujian toksisitas dilakukan dengan pemberian sediaan secara oral selama 28 hari pada 4 kelompok hewan coba uji, yaitu kelompok 1 diberi produk herbal X1, kelompok 2 diberi produk herbal X2, kelompok 3 diberi produk herbal X3 dan kelompok 4 diberi aquadest. Parameter toksisitas produk herbal yang digunakan adalah perubahan berat badan, indeks organ (hati dan ginjal), kadar SGOT dan SGPT, serta gambaran histopatologi organ hati. Hasil penelitian menunjukkan bahwa produk herbal X tidak menyebabkan efek toksik terhadap hewan coba.
\end{abstract}

Kata Kunci: produk herbal, toksisitas, histopatologi.

DOI: https://doi.org/10.25026/mpc.v9i1.341 


\section{PENDAHULUAN}

Penggunaan obat herbal telah diterima oleh hampir seluruh Negara di dunia. Di Negara-negara maju, penggunaan obat herbal tertentu sangat popular. Di Negara-negara sedang berkembang, sebagian besar penduduknya masih terus menggunakan obat herbal terutama untuk kebutuhan kesehatan dasarnya. Bahkan di Afrika, sekitar $80 \%$ masyarakat menggunakan obat herbal untuk pengobatan primer dan keperluan kesehatan [13]. Di Indonesia obat tradisional masih digunakan secara luas di masyarakat, baik pedesaan maupun diperkotaan [6]. Berdasarkan data hasil riset kesehatan dasar 2010, hampir setengah $(49,53 \%)$ penduduk Indonesia berusia 15 tahun ke atas, mengonsumsi jamu. Proporsi jenis jamu yang banyak dipilih untuk dikonsumsi adalah jamu cair $(55,16 \%)$; bubuk $(43,99 \%)$; dan jamu seduh $(20,43 \%)$. Sedangkan proporsi terkecil adalah jamu yang dikemas secara modern dalam bentuk kapsul/pil/tablet $(11,58 \%)$ [7].

Penggunaan obat herbal semakin meningkat sehingga diperlukan penelitian secara ilmiah tentang khasiat, keamanan dan standar kualitasnya agar penggunaannya sesuai dengan standar mutu yang telah ditetapkan. Untuk memenuhi standar mutu tersebut diperlukan upaya penegasan keamanan melalui uji praklinik yang meliputi uji ketoksikan dan khasiat. WHO juga mendukung upaya-upaya dalam peningkatan keamanan dan khasiat dari obat herbal [13].

Anggapan yang berkembang di masyarakat saat ini bahwa ramuan obat herbal yang berasal dari bahan alam tidak mempunyai efek samping sehingga tidak berbahaya. Anggapan ini tidak sepenuhnya benar karena hal tersebutlah maka dilakukan evaluasi keamanan suatu obat herbal untuk menguji potensi ketoksikan akut obat atau ramuan herbal. Kemajuan bidang farmasi di home industry dan meningkatnya permintaan obat-obat herbal di tengah masyarakat yang semakin pesat berefek pada timbulnya produk obat herbal yang tidak memenuhi persyaratan mutu dan keamanan, sehingga dapat merubah kemurnian obat-obat herbal tersebut.

Produk herbal X merupakan obat herbal tradisional yang beredar di Samarinda dan banyak digunakan oleh masyarakat. Masyarakat banyak mengonsumsi secara rutin tanpa mengetahui efek terhadap organ manusia jika dikonsumsi secara berlebihan. Penelitian mengenai toksisitas dan efek samping dari produk herbal $\mathrm{X}$ masih belum ditemukan tetapi pemanfaatannya dimasyarakat telah banyak dilakukan. Oleh karena itu perlu dilakukan pengujian lebih lanjut untuk melindungi masyarakat pengguna dari efek yang mungkin dapat merugikan dan untuk melihat ada tidaknya efek toksik sehingga menjamin keamanan penggunaannya.

\section{METODE}

Pelaksanaan penelitian telah mendapatkan persetujuan Komisi Etik Penelitian Kesehatan Fakultas Kedokteran Universitas Mulawarman dengan nomor 28/KEPK-FK/VII/2018 tertanggal 18 Juli 2018.

\section{Pembuatan Sampel Uji}

Bahan yang diteliti pada penelitian ini adalah produk herbal X1, produk herbal X2, produk herbal X3 yang beredar di Samarinda. Pembuatan sediaan produk herbal X1, X2 dan X3 dilakukan dengan cara ditimbang sesuai dengan perhitungan dosis kemudian dilarutkan dengan air hangat dan siap dilakukan pengujian.

\section{Penyiapan Hewan Uji}

Hewan uji yang digunakan adalah mencit (Mus musculus) galur DDY usia 8-12 minggu sebanyak 16 ekor. Sebelum mendapatkan perlakuan, 16 ekor mencit dikondisikan sebaik mungkin dengan ditempatkan pada suhu laboratorium, dan 
diberi pakan mencit (pellet) serta diberi minum. Mencit yang akan digunakan diadaptasikan dengan lingkungan minimal 1 minggu. Sebelum perlakuan, semua mencit ditimbang untuk mengetahui berat badan mencit. Mencit dibagi dalam 4 kelompok, yang terdiri dari masing-masing 4 ekor mencit.

\section{Pengujian Toksisitas}

Pengujian toksisitas produk herbal dilakukan dengan dikelompokkan hewan coba menjadi 4 kelompok yaitu kelompok kontrol negatif yang diberikan aquadest hangat, kelompok uji 1 yang diberikan produk herbal X1, kelompok uji 2 yang diberikan produk herbal X2 dan kelompok uji 3 yang diberikan produk herbal X3. Masing-masing kelompok terdiri dari 4 ekor mencit. Sebelum perlakuan semua mencit ditimbang untuk mengetahui berat badan dan diamati gejala klinis yang timbul. Diberikan perlakuan sesuai dengan kelompoknya. Diamati gejala klinis dan kematian pada 30 menit, 1 jam, 4 jam dan 24 jam. Dilanjutkan pemberian sediaan secara peroral sebanyak satu kali sehari selama 28 hari. Ditimbang berat badan hewan coba setiap 3 hari sekali. Diukur kadar SGOT dan SGPT kelompok uji dan kelompok kontrol negatif pada hari ke29. Kemudian hewan coba dikorbankan diambil hatinya untuk dibuat preparat untuk diamati profil histologi hati mencit dan perhitungan indeks organ. Jaringan kemudian dipreparasi dengan melakukan fiksasi menggunakan neutral buffered formalin dan dibuat preparat histologi yang dilakukan di laboratorium patologi anatomi RS Abdul Wahab Sjahranie dengan pewarnaan Hematoxyline Eosin terhadap organ.

Perhitungan indeks organ dilakukan dengan rumus:

$\%$ Bobot organ $=\frac{\text { bobot organ }}{\text { bobot badan }} \times 100 \%$

\section{HASIL DAN PEMBAHASAN}

Toksisitas didefinisikan sebagai suatu kemampuan zat kimia dalam menimbulkan kerusakan pada organisme baik saat digunakan atau saat berada dalam lingkungan. Toksisitas suatu bahan dapat diketahui dengan mempelajari efekefek pemaparan bahan terhadap organisme [3]. Obat herbal adalah obat dari tanaman yang diproses atau diekstrak sedemikian rupa sehingga menjadi serbuk, pil, atau cairan. Dalam proses pembuatannya, obat herbal tidak menggunakan zat kimia sintetik [5].

Pengujian toksisitas produk herbal $\mathrm{X}$ ini dilakukan untuk mengetahui keamanan dari produk herbal $\mathrm{X}$ jika dikonsumsi secara berulang dalam jangka waku tertentu dengan berpedoman pada peraturan BPOM tentang uji toksisitas nonklinik secara in vivo. Tujuan dari pengujian ini adalahuntuk mengetahui efek toksik dari produk herbal X.

Setelah dilakukan adaptasi selama 7 hari, hewan uji kemudian diberikan perlakuan sesuai dengan kelompoknya secara oral dan dilakukan pengamatan dan dilihat kematian hewan uji. Pengamatan dilakukan 30 menit, 1 jam, 4 jam dan 24 jam setelah pemberian sediaan. Berdasarkan pengamatan, tidak ada gejala toksik seperti kejang, diare, iritasi dan tidak ada tanda-tanda perubahan perilaku. Tidak ada kematian yang dilaporkan hingga 24 jam pada tiap kelompok uji dan kelompok kontrol. Berdasarkan hasil tersebut dapat diduga bahwa produk herbal X1, X2 dan X3 relatif aman karena selama 24 jam tidak menunjukkan kematian hewan uji sebanyak $50 \%$.

Setelah dilakukan pemberian sediaan uji dengan frekuensi 1 kali perhari selama 28 hari dan dilakukan pengamatan terhadap kondisi fisik hewan uji. Kondisi fisik hewan uji meliputi tingkah laku dan gejala toksik setelah perlakuan. Tujuannya untuk melihat adanya efek toksik yang terjadi akibat dari pemberian produk herbal $\mathrm{X}$. 
Pengamatan dilakukan dengan membandingkan antara kelompok uji dan kelompok kontrol. Berdasarkan pengamatan didapatkan adanya perbedaan tingkah laku yang berbeda antar kelompok perlakuan yaitu pada kelompok 1 salah satu hewan uji berputar-putar terus menerus pada hari ke-14 perlakuan. Tidak ditemukan gejala toksik pada sistem saraf dan pencernaan pada masing-masing kelompok dimana semua hewan uji tidak mengalami tremor, diare dan warna feses normal (hitam).

Pengamatan berat badan hewan uji dilakukan setiap 3 hari sekali selama pemberian perlakuan pada tiap kelompok. Terlihat berat badan hewan uji selama pemberian bahan uji rata-rata setiap kelompok berfluktuasi, namun secara umum menunjukkan pola penurunan berat badan dari awal pemberian sampai minggu ke-2. Kemudian naik kembali pada minggu selanjutnya. Hal tersebut berlaku untuk semua kelompok uji. Sedangkan untuk kelompok kontrol menunjukan pola kenaikan berat badan selama pengujian. Hal ini diduga karena pengaruh rasa dari produk herbal dimana rasa khas produk herbal yang digunakan adalahagak pahit dan agak pedas. Konsumsi pakan akan berefek secara langsung pada berat badan hewan coba. Pada studi toksisitas, hewan coba yang mendapat dosis tinggi umumnya akan kehilangan berat badan yang disebabkan penurunan nafsu makan [9]. Hasil pengamatan berat badan hewan uji dapat dilihat pada Tabel 1.

Tabel 1. Hasil Penimbangan Bobot Badan Mencit Selama Pemberian Sediaan

\begin{tabular}{lllllllllll}
\hline \multirow{2}{*}{ Kelompok } & \multicolumn{8}{c}{ Rata-Rata Bobot Badan $(\mathrm{g}) \pm$ SDV Pada Pengamatan Hari Ke- } \\
\cline { 2 - 11 } & \multicolumn{1}{c}{1} & \multicolumn{1}{c}{4} & \multicolumn{1}{c}{10} & \multicolumn{1}{c}{13} & \multicolumn{1}{c}{16} & 19 & \multicolumn{1}{c}{22} & 25 & 28 \\
\hline Kelompok 1 & $34 \pm 1$ & $34 \pm 2$ & $33,3 \pm 1,5$ & $33,3 \pm 3,1$ & $33,3 \pm 2,9$ & $33,7 \pm 4,2$ & $34,7 \pm 4,2$ & $34,3 \pm 6,4$ & $35 \pm 6,1$ & $37 \pm 4,4$ \\
Kelompok 2 & $32 \pm 0$ & $29 \pm 1,4$ & $24,5 \pm 0,7$ & $23,5 \pm 0,7$ & $23,5 \pm 2,1$ & $24 \pm 1,4$ & $23,5 \pm 2,1$ & $22,5 \pm 3,5$ & $22,5 \pm 4,9$ & $24 \pm 2,8$ \\
Kelompok 3 & $29,7 \pm 0,6$ & $28,7 \pm 2,1$ & $28 \pm 2,6$ & $27,7 \pm 4,7$ & $27,7 \pm 4,7$ & $28 \pm 4$ & $29 \pm 4,6$ & $29 \pm 4$ & $30,3 \pm 4$ & $30,7 \pm 3,5$ \\
Kelompok Kontrol & $26 \pm 1,4$ & $31 \pm 4,2$ & $31,5 \pm 2,1$ & $33 \pm 0$ & $34 \pm 1,4$ & $35,5 \pm 0,7$ & $36 \pm 1,4$ & $36 \pm 1,4$ & $38 \pm 2,8$ & $38,5 \pm 2,1$ \\
\hline
\end{tabular}

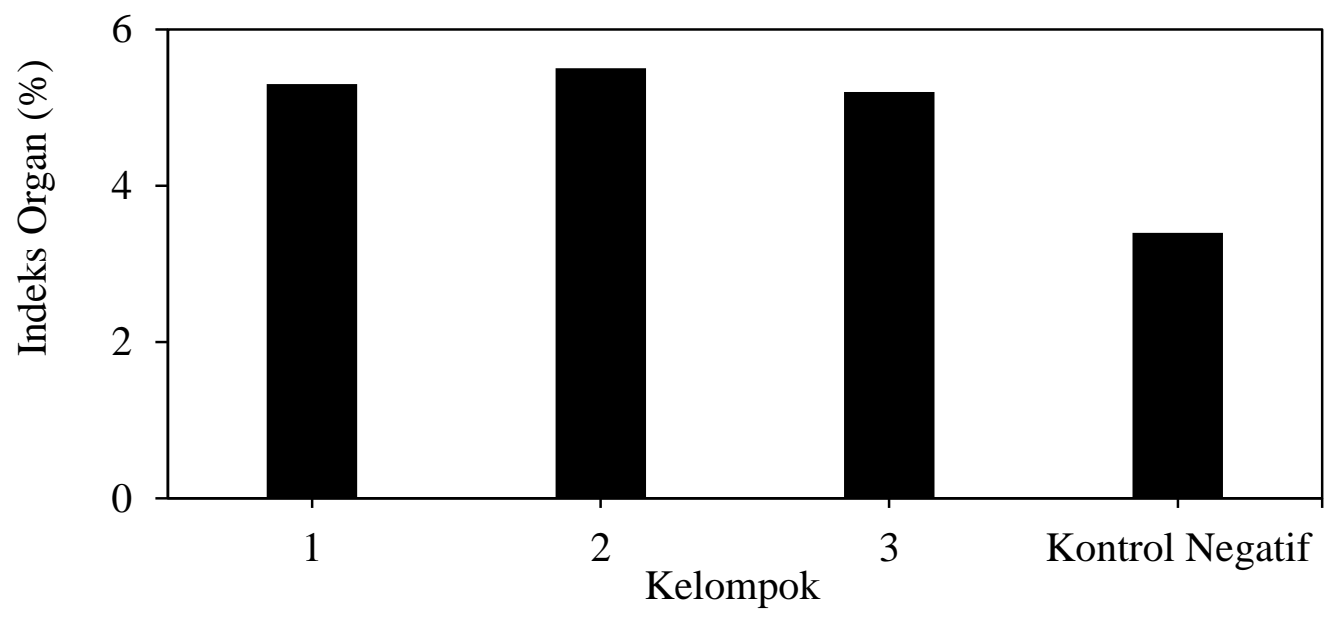

Gambar 1. Indeks Organ Hati 


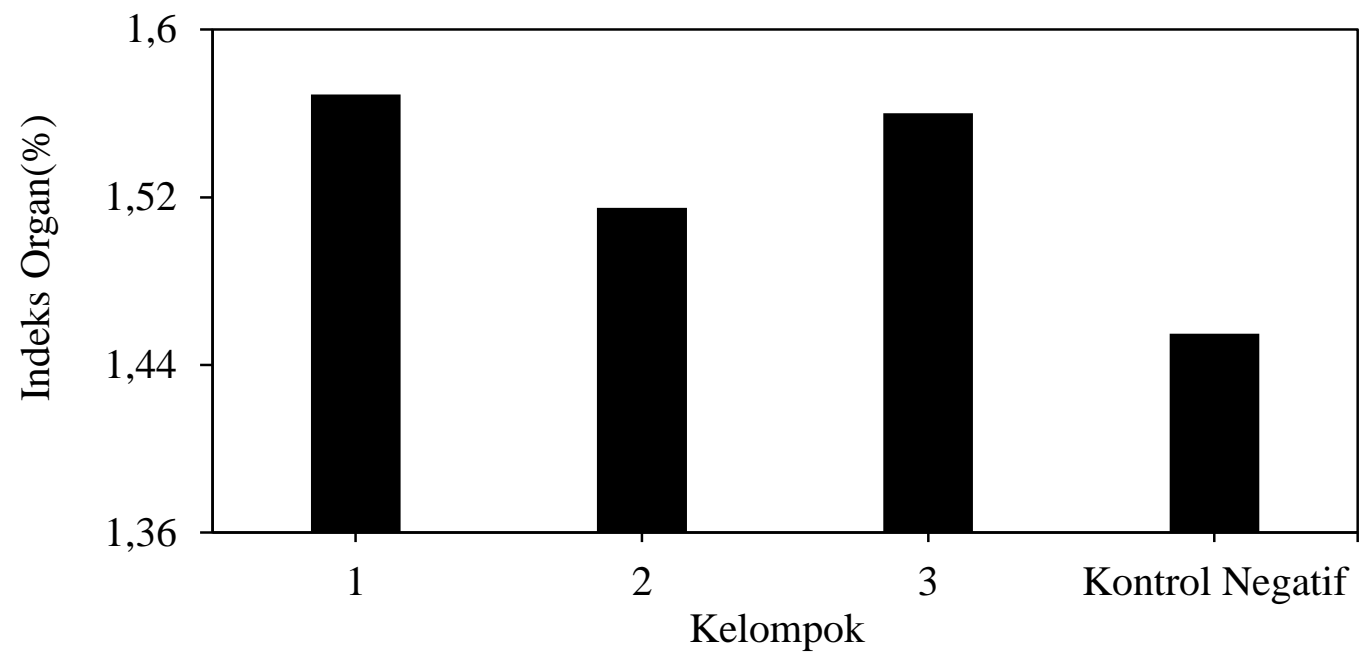

Gambar 2. Indeks Organ Ginjal

Setelah pemberian sediaan selama 28 hari, hewan uji dibedah dan ditimbang bobot organ dari setiap mencit pada setiap kelompok. Organ-organ yang diukur bobotnya adalah organ hati dan ginjal. Tujuan perhitugan indeks organ ini adalah untuk mengetahui adanya efek toksik pada organ dalam yang terjadi setelah pemberian sediaan. Grafik perhitungan indeks organ hati dan ginjal dapat dilihat pada Gambar 2 dan Gambar 3.

Hasil perhitungan indeks organ menunjukkan bahwa indeks organ hati dan ginjal mencit pada kelompok uji memiliki rerata indeks yang lebih tinggi dibandingkan dengan kelompok kontrol, namun tidak berbeda jauh.

Pemeriksaan uji fungsi hati merupakan salah satu pemeriksaan kimia yang seringkali dianggap sangat penting untuk menilai kesehatan. Hal ini dikarenakan peran hati sebagai organ tubuh yang penting dan merupakan organ pusat metabolisme. Hati menerima darah dari sirkulasi sistemik melalui arteri hepatica dan menampung aliran darah dari sistem porta yang mengandung zat makanan yang diabsorpsi di usus [8]. Hasil pemeriksaan kimia darah mencit untuk kandungan SGOT dan SGPT disajikan pada Tabel 2.
Tabel 2. Kadar SGOT dan SGPT Mencit Setelah Pemberian Sediaan

\begin{tabular}{lcc}
\hline \multicolumn{1}{c}{ Kode Sampel/ } & \multicolumn{2}{c}{ Hasil (IU/L) } \\
\cline { 2 - 3 } \multicolumn{1}{c}{ Kelompok } & SGOT & SGPT \\
\hline Kelompok 1 & 194 & 53 \\
Kelompok 1 & 177 & 43 \\
Kelompok 2 & 157 & 43 \\
Kelompok 3 & 170 & 45 \\
Kelompok 3 & 138 & 41 \\
Kelompok Kontrol & 81 & 26 \\
\hline
\end{tabular}

Berdasarkan data diatas dapat dilihat bahwa setelah pemberian sediaan, kandungan SGOT dan SGPT pada darah mencit kelompok uji 1, 2 dan 3 lebih tinggi dibandingkan dengan kelompok kontrol. Hal ini terkait dengan adanya kerusakan hati yang menyebabkan enzim ini dilepaskan kedalam darah. Fungsi utama enzim SGOT dan SGPT adalah sebagai biomarker atau penanda adanya gangguan pada hati. Namun perbedaan kadar SGOT dan SGPT antara kelompok uji dan kelompok kontrol tersebut bukan merupakan indikasi adanya kerusakan pada hati karena masih dalam rentang normal pada mencit. Nilai rujukan GOT untuk mencit adalah 70-400 IU/L. Sedangkan untuk kadar GPT normal 
dalam darah mencit adalah 25-200 IU/L [4]. Nilai SGOT yang berada sedikit diatas normal tidak selalu menunjukkan keadaan hati yang mengalami sakit. Diduga tidak semua peningkatan SGOT akibat dari gangguan pada hati. Kadar SGOT bergantung dari cara pengambilan darah, jumlah serum darah yang diperoleh, dan lama penyimpanan serum darah sebelum diperiksa dan umur hewan coba [8]. Apabila terjadi kerusakan sel yang parah maka akan terjadi kenaikan kadar SGPT dan SGOT secara bersamaan sampai dengan dua kali lipat bahkan hingga 20-100 kali dari kadar normal [10].

Tabel 3. Persentase Hepatosit Normal dan Hepatosit yang Mengalami Kerusakan Pada Hepar Setelah Perlakuan

\begin{tabular}{llll}
\hline Kelompok & \multicolumn{3}{c}{$\%$ Sel Hepatosit } \\
\cline { 2 - 4 } & Normal & Rusak Sebagian & Rusak Total \\
\hline Kelompok 1 & $71,43 \%$ & $28,57 \%$ & $0 \%$ \\
Kelompok 2 & $73,33 \%$ & $26,67 \%$ & $0 \%$ \\
Kelompok 3 & $79,69 \%$ & $20,31 \%$ & $0 \%$ \\
Kelompok 4 (K.Negatif) & $91,43 \%$ & $8,57 \%$ & $0 \%$ \\
\hline
\end{tabular}
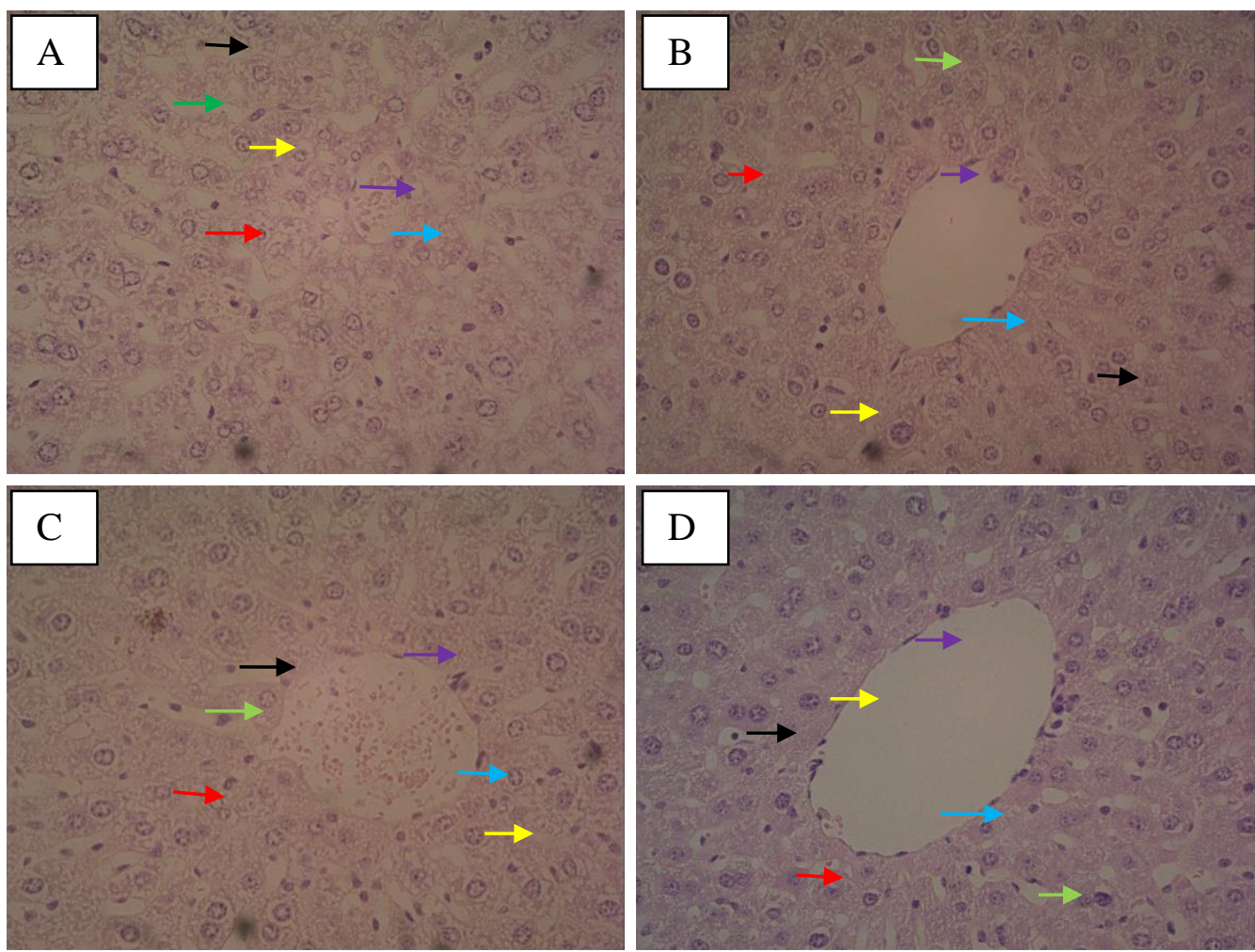

Gambar 3. Gambaran Histologi Hati Hewan Coba. (A) Kelompok 1 yang diberikan produk herbal X1; (B) Kelompok 2 yang diberikan produk herbal X2; (C) Kelompok 3 yang diberikan produk herbal X3; (D) Kelompok kontrol yang diberikan aquadest. Panah hitam menunjukkan sel kuffer, panah biru menunjukkan vena sentralis, panah ungu menunjukkan endotel, panah hijau menunjukkan sinusoid, panah kuning menunjukkan sel hepatosit normal, panah merah menunjukkan sel hepatosit yang mengalami degenerasi ringan. 
Hasil pengamatan histologi hati mencit rata-rata jumlah hepatosit normal maupun yang mengalami kerusakan setelah perlakuan ditunjukkan pada Tabel 3. Berdasarkan hasil tersebut dapat diduga bahwa produk herbal X1, X2 dan X3 relatif aman karena tidak menunjukkan kerusakan sel hepatosit sebanyak 50\%. Gambaran struktur histologis hati mencit pada perbesaran 400x dapat dilihat pada Gambar 3 . Hepatosit normal mempunyai ciriciri: sel tersusun secara radier terhadap vena sentralis, bentuk sel bulat dan oval dan terdapat lempeng-lempeng hepatosit. Sel terlihat memiliki satu nukleus, namun ada juga yang memiliki lebih dari satu nukleus (binucleat) yang terdapat ditengah sel [2]. Setiap lobulus hepar tersusun dari sel hepar dengan inti terpulas biru tua, memiliki kromatin tersebar, jelas dan menyerap zat warna kuat. Sitoplasma sel hepar terpulas merah merata dengan intensitas lebih kuat dibandingkan sitoplasma sinusoid yang berwarna merah muda [12]. Pada hasil pengamatan terlihat sel yang abnormal, namun sel hepatosit yang normal lebih dominan. Hanya beberapa sel hepatosit saja yang tampak mengalami degenerasi ringan. Hal ini didukung dengan pengamatan organ hati secara makroskopik dimana tidak ditemukan adanya perubahan warna dan permukaan hati mencit. Hati yang normal memiliki permukaan rata dan halus serta berwarna merah kecokelatan sedangkan hati yang abnormal memiliki permukaan seperti berupa jaringan ikat, kista maupun bintikbintik dan mengalami perubahan warna [11]. Umumnya perubahan makroskopis terjadi pada keadaan kronis. Dalam hepar, degenerasi ringan dapat tidak berpengaruh pada penampakan makroskopisnya [1]. Tidak ditemukan adanya kerusakan total berupa nekrosis pada sel hepatosit semua kelompok baik kelompok uji maupun kelompok kontrol. Kerusakan hepatosit berupa nekrosis ditandai dengan nukleus yang menghitam dan mengalami fragmentasi. Selain itu, hepatosit tampak semakin kecil dan mengkerut sehingga mempunyai bentuk yang tidak teratur [2]. Berdasarkan Gambar 3 menunjukkan area sinusoid terlihat normal atau tidak mengalami kerusakan sehingga disimpulkan bahwa tidak ada perdarahan pada kelompok uji dan kelompok kontrol. Area endotel tidak berbeda antara kelompok uji dan kelompok kontrol.

Keterbatasan dalam penelitian ini adalah sebelum pemberian sediaan uji tidak dilakukan pengukuran kadar SGOT dan SGPT dan tidak dilakukan pemeriksaan terhadap organ hati mencit sehingga kemungkinan saat mencit digunakan sebagai hewan uji sudah mengalami kerusakan sebelumnya. Keterbatasan lainnya adalah bisa karena faktor alat yang kurang memadai sehingga sampel serum sudah mengalami kerusakan sebelum dilakukan pengukuran kadar SGOT dan SGPT. Faktor-faktor lain yang mempengaruhi hasil penelitian kemungkinan adalah kondisi mencit yang tidak terkendali seperti mengalami sakit akibat faktor lain diluar pemberian sediaan seperti daya tahan dan kerentanan mencit yang menurun, faktor mencit yang mengalami stress, bertikai dengan sesama hewan uji dalam satu kandang, kondisi kandang yang kurang efektif, pemberian pakan dan minum yang belum sesuai standar, dan lain-lain.

\section{KESIMPULAN}

Berdasarkan hasil penelitian yang telah dilakukan dapat disimpulkan sebagai berikut:

a. Produk herbal $\mathrm{X}$ tidak toksik berdasarkan nilai kandungan SGOT dan SGPT mencit karena secara keseluruhan masih dalam rentang normal.

b. Produk herbal X tidak toksik berdasarkan profil histologi mencit. 
DAFTAR PUSTAKA

[1] Amalina, N. 2009. Uji Toksisitas Akut Ekstrak Valerian (Valeriana officinalis) Terhadap Hepar Mencit BALB/C. Fakultas Kedokteran Universitas Diponegoro, Semarang.

[2] Fajariyah, S., Utami,T.S., Arisandi, Y. 2010. Efek Pemberian Estrogen Sintesis (Diethylstillbestrol) Terhadap Struktur Hepar dan Kadar SGOT dan SGPT pada Mencit (Mus musculus) Betina Strain Balb'C. Jurnal Ilmu Dasar, 11(1).

[3] Farisi, S. Al, Munawir, A., \& Febianti, Z. 2015. Uji Toksisitas Akut Ekstrak Buah Bruguiera gymnorrhiza pada Tikus (Rattus norvegicus) (Acute Toxicity Test of Bruguiera gymnorrhiza Fruit Extract In Rats (Rattus norvegicus), E-Jurnal Pustaka Kesehatan, 3(2), 230-234.

[4] Hall, R.L. 2007. Clinical Pathology Of Laboratory Animals. In Animal Model in Toxicology. $2^{\text {nd }}$ edition. USA; CRC Press. p.789-828.

[5] Ismarani. 2013. Kajian Persepsi Konsumen Terhadap Penggunaan Obat Herbal (Kasus Di UNISMA Bekasi). Jurnal Agribisnis dan Pengembangan Wilayah, 4(2).

[6] Katno, P. S. 2010. Tingkat Manfaat dan Keamanan Tanaman Obat dan Obat Tradisional. Yogyakarta; Fakultas Farmasi, Universitas Gadjah Mada.

[7] Kementerian Kesehatan Republik Indonesia. 2011. Integrasi
Pengobatan Dalam Sistem Kesehatan

Nasional. Available from: www.depkes.go.id [dipublikasikan 02 November 2011].

[8] Krysanti, A dan Widjanarko, S. B. 2014. Toksisitas Subakut Tepung Glukomanan(A. muelleri Blume) Terhadap SGOT dan Natrium Tikus Wistar Secara In Vivo. Jurnal Pangan dan Agroindustri, 2(1).

[9] Ningsih, S, $d k k$. 2017. Uji Toksisitas Subkronik Kombinasi Ekstrak Daun Uncaria gambir dan Caesalpinia sappanJurnal Kefarmasian Indonesia, 7(1).

[10] Purwaningsih, S., Handharyan, E., Lestari, I. R. 2015. Pengujian Toksisitas Sub Akut Ekstrak Hipokotil Bakau Hitampada Tikus Galur Sprague Dawley. Jurnal Akuatika, 6(1).

[11]Robins, S. L dan Kumar, V. 1995. Buku Ajar Patologi I, $4^{\text {th }}$ ed. Jakarta; EGC.

[12] Sulistianto, D. E., Harini, M., Handajani, N. S. 2004. Pengaruh Pemberian Ekstrak Buah Mahkota Dewa [Phaleria macrocarpa (Scheff) Boerl] Terhadap Struktur Histologis Hepar Tikus Putih (Rattus norvegicus L.) Setelah Perlakuan dengan Karbon Tetraklorida $\left(\mathrm{CCl}_{4}\right)$ Secara Oral. Bio Smart, 6(2), 91-98.

[13] WHO, 2003. Traditional medicine, http://www.who.int/mediacentre/fact sheets/fs134/en/,diskesJanuari 2006 